\title{
$P-2452$ 種の新しいヒト腎癌細胞株の樹立
}

自治医科大学1、栃木県立がんセンター2)

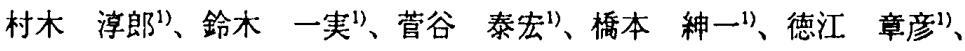

矢内原 仁2)、中菌 昌明2)

我々は、新たに2 種の堅癌細胞株(JMSU 2, JMSU 3)を樹立したのて、細胞の性状について報告する。患者は 女性、46歳と30歳。それぞれclear cell, spindle cell typeの督細胞落であり術前榇断はStage IV（リンバ節転移と骨 転移)であった。腎原発巣より組織を採取し細胞培盖を行い、現在まて 1 年 8 力と 1 年、順調に継代してい る。一例目は現在まで再発の所見なく生存しているか、二例目は術後急速な全身転移をきたし約 2 力の経過 で死亡した。いずれの症例も術前血清中CRPが高值を示すいわゆるRapid growing type と思われた。フローサイ トメーターを用いたJMSU 2 綀胞の DNA indexは1.81,JMSU 3細胞は1.17でった。G-bandingによる染色体分析 では、JMSU 2は84にモードを示すとト型染色体で第 3 染色体短腕欠損などの異常、JMSU 3は55にモードを示 し第 1 染色体短腕欠損などの異常が見られた。培義上清中には、JMSU $3 の み 6,340 \mathrm{pg} / \mathrm{ml}$ のG-CSFが観察された。 IL-1 $\alpha$ はいずれの細胞培養上清にも見られなかったが、IL-1 $\beta$ はJMSU 2細胞、JMSU 3綀胞それぞれの培意上 清で31 pg/mlと $25 \mathrm{pg} / \mathrm{ml}$ ，GM-CSFは $131 \mathrm{pg} / \mathrm{ml}$ と $29 \mathrm{pg} / \mathrm{ml}$ ，IL-6は $1,800 \mathrm{pg} / \mathrm{ml}$ と $145,000 \mathrm{pg} / \mathrm{ml}$ ，IL-8は $33.5 \mathrm{pg} / \mathrm{ml}$ $35,300 \mathrm{pg} / \mathrm{ml}$ 浱度で認められ、二つの細胞株とも多種のサイトカインを産生する厘湟であることが判明した。 電子顕微鏡検查では、豊富なクリリコーゲン顆粒やMicrovilliなど腎癌由来の細胞に矛盾しない所見であった。 JMSU 3 はヌードマウスに可移植性であり、原発巣類似の紡鍾細胞が in vivoで再現しえた。

\section{$P-246$ 㫮細胞癌における染色体 $3 p, 5 q$ 及び17p 欠失}

岩手医大泌沓器科1)、岩手医大第二病理2

杉村淳1、2)、鈴木泰2)、田村元2)、藤岡知昭1)、久保隆 1$) 、$ 里舘良一2)

【日的】腎癌では、他の悪性腫境で高摔に見い出される癌遗伝子あるいは癌抑制遺伝子の異常が検出 される率が低いことから、他の悪性腫瘍とは遺伝子的発生経路がかなり異なっていると推測される (Virchows Arch., 1994)。本研究では、腎癌に特異的な遺伝子変化と考えられるVHL (von Hippel-Lindau disease) 遺伝子罂失の頻度、意義を明らかにする目的でpolymorphic microsatellite markerを用いたPCRLOH解析を行った。また、腎癌の抑制遺伝子の存在が示唆されている5qの共通欠失領域の同定を試み た。他の瑟性腫瘍で高率に久失が認められる17p (TP53 locus)の欠失も検索した。【対象と方法】1991 年2月から 1995年7月までに岩手医科大学泌尿器科及びその関連病院で行われた腎瘦の手術検体45例を 対象とした。3p (D3S1317)、5q (D5S428, D5S346, D5S210, FBN2, IRF-1, D5S178, D5S209)、17p (TP53) 上の訫 9 個の microsatellite markerを用いてPCR-LOH解析を行った。【結果】3pについては40\% (12/30

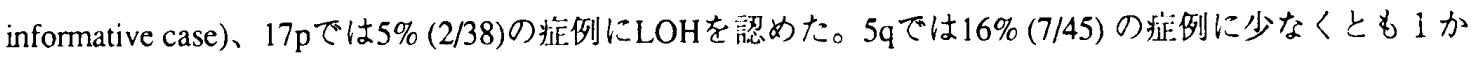
所の microsatellite marker でLOHを認めた。5qで最も高㳯 $(21 \% ; 6 / 28)$ にLOHが検拄されたのは、IRF-1 (interferon regulatory factor-1 locus) であり、IRF-1が5qの共通欠失領域と考えられた。3pあるいは5q (IRF-i locus)にLOHを認めた症例の組織型が、すべて明細胞型あるいは混命細胞型の症例であった以 外には、これらの染色体火失と臨床病理学的事項の問には有意の関連性は認められなかった。また、 3p と $5 q$ の涔方にLOHを認める症例は1例のみだった。【結論】3p (VHL locus) と5q(IRF-1 locus)の久 失は、明細胞型腎癌の発生に重要な遗伝子变化と考えられる。一方、他の瑟性腫瘍で高率に見い法さ れる17p (TP53 locus)の欠失は腎癖ては稀であった。 